\title{
JUDICIAL REVIEW UNDER THE OCCUPATIONAL SAFETY AND HEALTH ACT: THE SUBSTANTIAL EVIDENCE TEST AS APPLIED TO INFORMAL RULEMAKING
}

In Associated Industries v. Department of Labor the Court of Appeals for the Second Circuit held that standards established by the Secretary of Labor pursuant to the Occupational Safety and Health Act of $1970^{2}$ (OSHA) as well as the factual determinations underlying those standards are subject to the substantial evidence test of judicial review, ${ }^{3}$ even though those standards are adopted pursuant to informal rulemaking procedures. ${ }^{4}$ In reaching its decision, the Second Circuit became the first court to interpret the apparent inconsistency between the rulemaking procedures and the standard of judicial review embodied in this highly significant legislation. ${ }^{5}$

Congress enacted the Occupational Safety and Health Act for the purpose of assuring "so far as possible every working man and woman in the Nation safe and healthful working conditions ...." As a

1. 487 F.2d 342 (2d Cir. 1973).

HEREAFTER THE FOLLOWING CITATIONS WILL BE USED IN THIS NOTE:

Hamilton, Procedures for the Adoption of Rules of General Applicability: The Need for Procedural Innovation in Administrative Rulemaking, 60 CALIF. L. REv. 1276 (1972) [hereinafter cited as Hamilton];

Scalia \& Goodman, Procedural Aspects of the Consumer Product Safety Act, 20 U.C.L.A. L. Rev. 899 (1973) [hereinafter cited as Scalia \& Goodman].

2. 29 U.S.C. $\$ \S 651$ et seq. (1970).

3. 487 F.2d at 349 . The section of the Act governing judicial review of standards promulgated thereunder, states only that "determinations of the Secretary shall be conclusive if supported by substantial evidence . . , " 29 U.S.C. \$ 655(f) (1970) (emphasis added), and thus leaves room for the question of whether both the policy determination embodied in the standard as well as the factual findings on which that standard is based must be supported by substantial evidence. See notes 55,56 infra and accompauying text for a discussion of the arguments made on both sides of this question.

4. The substantial evidence test is usually associated with formal adjudicatory proceedings, whereas the primcipal alternative standards of agency review, the arbitrary and capricious test, generally governs review of informal rulemaking. These standards of review are discussed in notes 16-33 infra and accompanying text.

5. The broad importance of OSHA may be seen in the fact that it covers approxinately 57 million employees and 4.1 million businesses. Moreover, it is estimated that enforcement of the Act will necessitate a total of approximately 2000 inspectors and trial judges. See White \& Carney, OSHA Comes of Age: The Law of Work Place Environment, 28 Bus. LAw. 1309 (1973), and citations therein.

6. 29 U.S.C. $\$ 651$ (b) (1970). OSHA was enacted by Congress in December 
part of the statutory plan, the Secretary of Labor is authorized to promulgate occupational safety and health standards ${ }^{7}$ in the form of national consensus standards, ${ }^{8}$ temporary emergency standards, ${ }^{0}$ and permanent standards. ${ }^{10}$ To avoid delay in the establishment of certain

1970 and became effective April 28, 1971. The Act is applicable to any employers, including corporations, who engage in a business affecting interstate commerce. Id. $\$ \S 652(3)$, (5) (1970). For general discussions of the Act, see Brady, The New Occupational Safety and Health Act-Its Impact on Contractors and Sureties, 8 THE Forum 114 (1972); Gross, The Occupational Safety \& Health Act: Much Ado About Something, 3 LoyoLA CHr. L.J. 247 (1972); Horneberger, Occupational Safety and Health Act of 1970, 21 Cleve. ST. L. Rev. 1 (1972); Moran, A Critique of the Occupational Safety and Health Act 1970, 67 Nw. U.L. Rev. 200 (1972); Spann, The New Occupational Safety and Health Act, 58 A.B.A.J. 255 (1972); Note, The Occupational Safety and Health Act of 1970: Some Unresolved lssues and Potential Problems, 41 GEO. Wash. L. REv. 304 (1972).

7. 29 U.S.C. $\$ 651(b)(3)$ (1970). The "term 'occupational safety and health standard' means a standard which requires conditions, or the adoption or use of one or more practices, means, methods, operations, or processes, reasonably necessary or appropriate to provide safe or healthful employment and places of employinent." Id. $\S 652(8)$.

In addition to requiring compliance with the "occupational safety and liealth standards" proinulgated by the Secretary, the Act also mandates that employers adhere to a "general duty clause." Id. $\$ 654(\mathrm{a})(1)$. Under this clause, each employer is required to "furnish to each of his employees employment and a place of employment which are free from recognized hazards that are causing or are likely to cause dcath or serious physical harm to his employees." Id. For a general discussion of this clause, see Morey, The General Duty Clause of the Occupational Safety and Health Act of 1970, 86 HARV. L. REv. 988 (1973).

8. 29 U.S.C. $\$ 655(\mathrm{a})$. As defined in the Act, the term "national consensus standard" means:

[A]ny occupational safety and health standard ... which (1) has been adopted and promulgated by a nationally recognized standards-producing organization under procedures whereby it can be determined by the Secretary that persons interested and affected by the scope or provisions of the standards have reached substantial agreeinent on its adoption, (2) was formulated in a manner which afforded an opportunity for diverse views to be considered and (3) has been designated as such a standard by the Secretary, after consultation with other appropriate Federal agencies. Id. $\$ 652(9)$.

9. 29 U.S.C. $\$ 655$ (c) (1970). An emergency temporary standard may be issued if the Secretary determines "(A) that employees are exposed to grave danger from exposure to substances or agents determined to be toxic or physically harmful or from new hazards, and (B) that sucl emergency standard is necessary to protect employees from such danger." Id. $\$ 655$ (c)(1). Upon publication of the emergency temporary standard in the Federal Register, the Secretary is required to commence informal rulemaking proceedings and, within six months after such publication, to promulgate a permanent standard. Id. $\$ 655(\mathrm{c})(3)$.

10. Id. $\S 655(\mathrm{~b})$. The term "permanent standards" is used to refer to those standards issued pursuant to informal ruleinaking procedures of OSHA as provided for in subsection $6(\mathrm{~b})$ of the Act, id., described in note 13 infra. It should be noted, however, that "national consensus standards" are no less permanent than those standards issued pursuant to subsection $6(\mathrm{~b})$. Id. $\$ 655(\mathrm{a})$. Both standards are subject to attack for only 60 days after promulgation and both remain in force until modified 
minimum standards, the Act permitted the issuance of national consensus standards during the two-year period immediately following its effective date ${ }^{11}$ and of temporary emergency standards at any time, without regard to the rulemaking procedures otherwise applicable under the Administrative Procedure Act (APA) and OSHA. ${ }^{12}$ The promulgation of permanent standards, on the other hand, is made subject to informal notice-and-comment rulemaking procedures, with the additional requirement that a legislative-type learing must be held upon the written request of any interested person..$^{13}$

Judicial review is made available to any person who may be adversely affected by a standard issued under the Act. ${ }^{14}$ As to the standard to be applied in that review, the Act specifically provides that the "determinations of the Secretary shall be conclusive if supported by substantial evidence in the record considered as a whole."

or otherwise revoked by the Secretary in accordance with subsection $6(\mathrm{~b})$. Id. $\S$ 655(f).

11. Because OSHA became effective on April 28, 1971, this two-year period ended on April 28, 1973. Occupational Safety and Health Act, Pub. L. 91-596, § 1, 84 Stat. 1590 (Dec. 29, 1970).

12. The informal procedures which would otherwise be applicable under OSHA, 29 U.S.C. $\$ 655$ (b) (1970), and under section 4 of the APA, 5 U.S.C. $\$ 553$ (1970), are discussed in notes 20-24 infra and accompanying text; the formal adjudicatory procedures sometimes applicable nnder sections 7 and 8 of the APA are discussed in notes 16-19 infra and accompanying text.

Althougl these procedures are not applicable to national consensus and emergency standards, it should nonetheless be recalled that both of those standards are subject to substantial conditions precedent to their issuance. See notes 8 \& 9 supra. Moreover, it shonld also be noted that when the Secretary promulgates an emergency standard, that promulgation is to "include a statement of the reasons for snch action." 29 U.S.C. $\$ 655(\mathrm{e})(1970)$.

13. The procedural provisions of OSHA establish the following steps for rulemaking: (1) the Secretary determines that a rule should be proinulgated and publishes a proposed rule; (2) interested parties are allowed to submit written data or comments within thirty days after publication of the proposed rule; (3) if requested within thirty days after pnblication of the proposed rule, a pnblic hearing is to be held; (4) within sixty days after the expiration of the period or written comment or after the completion of a hearmg, the Secretary is required to issue a rule or make the determination not to issue a rule. 29 U.S.C. $\$ \S 655$ (b) (1)-(4) (1970). In addition to the pnblication of the final rule, the Secretary is also required to make a statement as to the reasons for his actions. Id. $\$ 655(\mathrm{e})$.

Although the Act does not specify the exact format to be used in the hearing, it has been recognized that the Act provides for notice-and-comments rulemaking as opposed to on the record proceedings. See Associated Indus. v. Department of Labor, 487 F.2d 342 (2d Cir. 1973); Conference Report, H.R. REP. No. 91-1765, 91st Cong., 2d Sess. 34 (1970). Consistent with this interpretation of OSHA, the Secretary has issued regulations which provide for informal rulemaking procedures. 29 C.F.R. $\$ 1911.15$ (1973).

14. 29 U.S.C. $\$ 655(f)(1970)$.

15. $I d$. Althougli the statute merely provides that the determinations shall be up- 
Thus OSHA apparently provides for the application of the substantial evidence test to the Secretary's determinations, while simultaneously directing that such determinations be made pursuant to informal rulemaking procedures. Utilization of the substantial evidence standard to review informal rulemaking procedures is anomalous, however, since such procedures do not produce the formal evidentiary record to which that standard is normally applied.

Under the APA, the substantial evidence test applies only to rules "required by statute to be determined on the record after opportunity for an agency hearing." 16 Where an agency is required to promulgate rules "on the record," the formal rulemaking procedures provided in sections 7 and 8 of the APA ${ }^{17}$ must be followed. These formal procedures require that rulemaking be conducted in the context of adjudicatory hearings which include the right to submit oral evidence and to conduct cross-examination. ${ }^{18}$ Thus, a formal evidentiary record is developed upon which the agency's decision nnust be based. On review the court examimes this formal record in order to determine whether the final rule is supported by substantial evidence therein. ${ }^{19}$

In contrast, where an agency issues rules pursuant to the informal notice-and-comment rulemaking provisions prescribed in section 4 of the APA, no evidentiary record is compiled. ${ }^{20}$ Rather, in informal rulemaking ${ }^{21}$ the agency must merely give proper notice of proposed

held if supported by substantial evidence, the necessary implication of that provision is that the Secretary's determinations are to be held invalid if they are not so supported. See Mobil Oil Corp. v. FPC, 483 F.2d 1238, 1257 n.68 (D.C. Cir. 1973).

16. 5 U.S.C. $\$ \S 553(\mathrm{c}), 706(2)$ (E). As noted by the Court of Appeals for the District of Columbia Circuit, the substantial evidence test is generally associated with formal rulemaking:

Although formal ruleinaking proceedings are subject to both standards, the "substantial evidence" standard of judicial review "is usually the handmaiden of [formal] procedures, whereas [informal] rule-making proceedings are reviewed under the inore narrow "arbitrary and capricious' standard." Texas Gulf Coast Area Natural Gas Rate Cases, 487 F.2d 1043, 1069 n.59 (D.C. Cir.), petition for cert. filed, 42 U.S.L.W. 3387 (U.S. Dec. 21, 1973) (No. 73-969).

17. 5 U.S.C. $\$ \$ 556,557$ (1970). Rather than requiring a higher degree of support for the upholding of an agency determination, the true constraint of the substantial evidence test is said to be its inandate that the pertinent support be "containcd within the confines of the public record made pursuant to the provisions of sections 556 and 557 of the Administrative Procedure Act." Absent such confines, the commentators maintain that there can be no such constraint. Scalia \& Goodman 934-35.

18. 5 U.S.C. $\$ \S 556,557$ (1970). Formal rulemaking has been described as "legislation by adjudication" and "rulemaking on a record." Hamilton 1277.

19. 5 U.S.C. $\$ 706(2)$ (E) (1970).

20. Id. $\$ 553$.

21. Informal rulemaking, which is also referred to as notice-and-comment rule- 
rulemaking in order that interested parties be given an opportunity to participate "through submission of written data, views or arguments with or without opportunity" for oral presentation. ${ }^{22}$ Rules promulgated pursuant to such procedures inust incorporate a concise general statement of their basis and purpose, ${ }^{23}$ and will be held invalid only if found to be arbitrary or capricious. ${ }^{24}$ Thus, under the APA, rules promulgated pursuant to informal procedures are subject to the arbitrary and capricious standard of review, while those adopted through formal procedures are subject to the substantial evidence standard. ${ }^{25}$

While the substantial evidence test is often considered a "stricter" standard of review than that afforded by the arbitrary and capricious test, it is difficult to articulate a meaningful distinction between the two tests as standards of review. ${ }^{26}$ Commentators have

making, applies "to the great bulk of grants of rulemaking authority to Federal agencies." Hamilton 1276.

22. 5 U.S.C. $\$ 553(\mathrm{c})(1970)$. The distinction between informal and formal rulemaking has been analogized "to the distinction between a hearing before a legislative body and a liearing before a court." Hamilton 1277.

Professor Hamilton has stated that the APA is "polar" with respect to rulemaking procedures, in that it prescribes only formal and informal procedures with no alternative or internediate procedures between those two principal forms of rulemaking. Id. This position has recently been rejected, however, by the Court of Appeals for the District of Columbia Circuit. That court maintains that, rather than being mutually exclusive, the informal and formal procedures set forth in the APA merely establish the "outer boundaries of administrative procedures"-the former representing the "minimum protections upon which administrative action may be based" and the latter delineating the "highest degree of administrative protection that Congress beheved would be necessary to protect interested parties." In between these boundaries, any possible formulation of formal and informal procedures would be possible. Mobil Oil Corp. v. FPC, 483 F.2d 1238, 1253 (D.C. Cir. 1973). See also City of Chicago v. FTC, 458 F.2d 731 (D.C. Cir. 1971).

23. 5 U.S.C. $\$ 553($ c) $(1970)$.

24. Id. $\$ 706(2)(\mathrm{A})$.

25. It should be noted that in addition to being subject to the substantial evidence test, rules promulgated under formal procedures are also subject to the arbitrary and capricious test. 5 U.S.C. $\$ 706$ (1970); Citizens To Preserve Overton Park v. Volpe, 401 U.S. 402, 413-14 (1971). Moreover, agency actions taken pursuant to either formal or informal procedures will also be set aside if the reviewing court finds them to be (1) "contrary to constitutional right, power, privilege or immunity," (2) "in excess of statutory jurisdiction, authority, or limitations, or sloort of statutory right," (3) "without observance of procedure required by law," or (4) "unwarranted by the facts to the extent that the facts are subject to trial de novo by the reviewing court." 5 U.S.C. $\$ 706(2)(B),(C),(D),(F)(1970)$.

26. With regard to the arbitrary and capricious test, the Supreme Court has stated that it is the function of the reviewing court to deternine whether the agency's "decision was based on a consideration of relevant factors and whether there has been a clear error of judgment." Citizens To Preserve Overton Park v. Volpe, 401 U.S. 402,416 (1970). See L. JAFFE 182. As for the substantial evidence test, the Supreme Court has observed that it is the court's duty to determine whether the "evidence . . . is substantial, that is [whether it affords] a substantial basis of fact from which the 
noted that where an agency determination is challenged because of the inadequacy of its evidentiary basis, "it is difficult to imagine a decision having no substantial evidence to support it which is not also 'arbitrary,' or a decision struck down as arbitrary which is in fact supported by 'substantial evidence." "2t Thus, some cominentators have concluded that froin an evidentiary standpoint "the level of required support seems about the same whether the 'substantial evidence' or the 'arbitrary' test is used."28 Similarly, Professor Davis has suggested that whatever distinction might be drawn would be too fine for "practical application." 29

Rather than imposing a higher standard of review, the significance of the imposition of the substantial evidence test hes in the nature of the record to which it is applied. ${ }^{30}$ The Supreme Court las held that when determining whether an agency's actions are supported by substantial evidence, the reviewing court is required to consider the whole record and not merely the evidence which tends to support the agency's position. ${ }^{31}$ More recently, the Court of Appeals for the District of Columbia Circuit lias concluded that "th[is] rule that the 'whole record' be considered-both evidence for and against-means that the procedures must provide some mechanism for interested parties to introduce adverse evidence and criticize evidence introduced by others."32 Thus, the significant constraint of the substantial evi-

fact in issue can be reasonably inferred ...." NLRB v. Columbian Enameling \& Stamping Co., 306 U.S. 292, 299 (1939). Although the Columbian Enameling case was decided prior to the passage of the APA, the Supreme Court subsequently observed that the change provided by the APA was "not a change in the basic test but in the application of that test . . ." Universal Camera Corp. v. NLRB, 340 U.S. 474 (1951); see $4 \mathrm{~K}$. Davis $\$ 29.02$, at 118-20. Due to the court's inability to distinguisl these standards, some coinmentators liave called for the abandonment of the substantial evidence test. See Cooper, Administrative Law: The "Substantial Evidence" Rule, 44 A.B.A.J. 945 (1958).

27. Scalia \& Goodman 935 n.138.

In Associated Industries, while conceding the possible existence of cases in which the two standards might produce different results, the court gave its qualified endorseneent to the proposition that the two standards are substantively similar. $487 \mathrm{~F} .2 \mathrm{~d}$ at 352. See note 59 infra and accompanying text. But see Cliarlton v. United States, 412 F.2d 390, 398 (3d Cir. 1969) (Stahl, J., concurring).

28. Scalia \& Goodinan 935 n.138. But see Wright, The Courts and the Rulemaking Process: The Limits of Judicial Review, 59 CORNELL L. Rev. 375, $391-93$ (1974).

29. $4 \mathrm{~K}$. Davis $\$ 29.02$, at 126 .

30. See, e.g., Mobil Oil Corp. v. FPC, 483 F.2d 1238, 1257-64 (D.C. Cir. 1973); Scalia \& Goodinan 934-36.

31. See Universal Camera Corp. v. NLRB, 340 U.S. 474, 488 (1951).

32. Mobil Oil Corp. v. FPC, 483 F.2d 1238, 1258 (D.C. Cir. 1973) (empliasis omitted). The Court of Appeals for the District of Colunibia Circuit, in revieving the provisions of the Natural Gas Act, 15 U.S.C. $\$ \$ 717$ et seq. (1970), governing agency procedures and judicial review thereunder, noted that the 
dence test lies not in the amount of probity of the evidence required by the test, but instead in the test's requirement that the agency base its decision solely upon a record containing evidence whicli lias been introduced and tested by adversary, adjudicative-type procedures of soine nature. In this context, it has been observed that the substantial evidence test would at best be difficult to apply to agency determinations made pursuant to the informal rulemaking procedures prescribed in section 4 of the APA:

The record in ... [an informal rulemaking proceeding] ordinarily will contain nore generalized than specific information, may not contain information tested by cross-examination and will frequently contain much conclusory information based on data gathered by the imterested parties. For this reason, application of the substantial evidence test ... to findings resulting from [an informal rulemaking] proeeeding would be of scant utility. ${ }^{33}$

Because of the apparent incompatibility of the substantial evidence test with informal rulemaking, ${ }^{34}$ it is difficult to perceive why Congress
language [of the APA] indicates that Congress expected that the substantial evidence test would be used in conjunction with formal procedures under sec- tion[s] [7 and 8 of the APA]. Thus Congress, in using the phrase "substantial evidence" in another statute, undoubtedly thought that similar procedures would be used in creating this evidentiary record. This supports the conclu- sion that the requirement of facts based on substantial evidence mandates greater procedural protection than those accorded under section [4] of the APA. 483 F.2d at 1258 n.70.

33. City of Chicago v. FPC, 458 F.2d 713, 744 (D.C. Cir. 1971). In Mobil Oil Corp. v. FPC, 483 F.2d 1238 (D.C. Cir. 1973), the court described this seeming incongruity between the substantial evidence test and informal rulemaking procedures in similar language:

Informal comments simply cannot create a record that satisfies the substantial evidence test. Even if controverting information is submitted in the form of cominents by adverse parties, the procedure employed cannot be rehed upon as adequate. A "whole record," as that phrase is used in this context, does not consist merely of the raw data introduced by the parties. It includes the process of testing and illumination ordinarily associated with adversary adjudicative procedures. Without this critical element, informal commeuts, even by adverse parties, are two halves that do not make a whole. Id. at 1260.

Dne to the failure of informal procedures to impose constraints on the contents of the record, two commentators have noted that the substantial evidence test is "only rationally applicable" to formal rulemaking procedures. Scalia \& Goodman 934. See also General Tel. Co. v. United States, 449 F.2d 846 (5th Cir. 1971); Boating Indus. Ass'n v. Boyd, 409 F.2d 408 (7th Cir. 1969); Autonotive Parts \& Accessories Ass'n v. Boyd, 407 F.2d 330 (D.C. Cir. 1968). Moreover, it shonld be noted that while informal ruleniaking procedures may create a record, see $i d$. at 336, such procedures are "not designed to produce a record that is to be the basis of agency action-the basic requirement for substantial-evidence review." Citizens To Preserve Overton Park v. Volpe, 401 U.S. 402,415 (1971).

34. While there is some dispute as to whether the APA is polar with respect to rulemaking procedures, see note 22 supra, that is, whether the Act recognizes only formal or informal procedures with no intermediate alternatives-it is certain that both 
would have chosen to force such an awkward coexistence between the two in the rulemaking and judicial review provisions of OSHA. A brief examination of the legislative history of that Act's procedural provisions, however, reveals the origins of this apparent anomaly.

As initially passed by the Senate, the occupational safety and health bill expressly provided that the establishment of standards would be performed in accordance with the informal rulemaking procedures of the APA. ${ }^{35}$ Since the Senate bill was silent as to the scope of judicial review, those rulemaking procedures would only lave been subject to the arbitrary and capricious test. ${ }^{36}$ In contrast to the Senate bill, however, the House version of OSHA explicitly required that safety and liealth standards be promulgated under the formal ruleinaking procedures provided in the $\mathrm{APA}_{0}{ }^{37}$ which would have imvoked the substantial evidence standard of judicial review. ${ }^{38}$ In the Conference Committee, the House conferees accepted the informal rulemaking procedures provided in the Senate version. ${ }^{39}$ With regard to the standard of review to be adopted, however, the Conference Report contains the following statement:

The "substantial evidence" test was the basis of court review in the House amendment; in the Senate bill, the more vigorous standards generally applicable to review of rules would have been applicable

forms of rulemaking are subject to substantial criticism. Professor Davis has described formal rulemaking as being fundamentally undesirable, and Professor Hamilton has suggested that such procedures may be "time-consuming, expensive, and unduly burdensome ou administrative agencies." $1 \mathrm{~K}$. DAvIS $\S$ 6.02; Hamilton 1278-1313. Informal rulemaking procedures, ou the other hand, have been attacked as being insensitive to written and oral comments submitted by persons who might be affected by a proposed rule. See Hamiltou 1314.

A desire simultaneously to avoid both types of criticisms may have played a substantial role in the presence in other recent federal statutes such as the Consumer Product Safety Act, 15 U.S.C.A. $\S \S 2051$ et seq. (Supp. 1974) and the Federal Coal Mine and Safety Act of 1969, 30 U.S.C. $\S \S 801$ et seq. (1970), of provisions applying the substantial evideuce test to informal rulemaking. See Hamilton 1319-26.

35. 116 CoNG. REC. 37,633-34 (1970).

36. As noted previously, under the APA the substantial evidence test is only applicable to the review of agency actions taken pursuant to sections 7 and 8 of the Act or to cases "otherwise reviewed on the record of an agency hearing provided by statute." 5 U.S.C. $\$ 706(2)$ (E) (1970). Since the Senate version did not require OSHA standards to be adopted "on the record," only those review provisions associated with informal rulemaking procedures would have apphied. See Umited States v. Florida East Coast Ry. Co., 410 U.S. 224 (1973); United States v. Allegheny-Ludlum Steel Corp., 406 U.S. 742 (1972).

37. 116 CONG. REC. 38,725 (1970).

38. Id. See 5 U.S.C. $\$ 706(2)(E)$ (1970). See note 19 supra and accompanying text.

39. H.R. REP. No. 1765, 91st Cong., 2d Sess. 34 (1970), reprinted in 3 U.S. CODB CONG. \& AD. NEwS 5230 (1970). 
.... [T]he "substantial evidence" test ... [was] accepted by the conferees. ${ }^{40}$

The blatant paradox in the conferees' statement is found in the fact that there are no "generally applicable" review standards which are "more vigorous" than the substantial evidence test.41 Yet, despite the apparent confusion manifested in the above statement, it would appear that the Conference Committee accepted the Senate bill's mode of procedure while adopting the House version's standard of review. This view is supported by statements made by Congressman Steigler, the chief House sponsor of the Act. In urging the House to adopt the conference-reported bill, he referred solely to the supervisory protection provided by the substantial evidence rule rather than to the benefits of formal rulemaking:

The Sccretary's standard will only be sustained by the court if it is supported by "substantial evidence on the record considered as a whole ...." [T] he court review based upon substantial evidence provides a sufficient element of fairness to satisfy me that [the] conference report should be accepted. ${ }^{42}$

Thus, the legislative history of OSHA indicates that, notwithstanding the absence in the Act of formal rulemaking requirements, Congress intended to subject the standards promulgated thereunder to the substantial evidence test.

It was in the mescapable light of this rather martful congressional compromise that the Second Circuit was called upon to decide Associated Industries v. Department of Labor. ${ }^{43}$ In May, 1971, the Secretary of Labor, under the authority granted to him in the Act, promulgated a general sanitation standard which required that all places of employment, both industrial and nonindustrial, provide at least one lavatory for every ten employees, up to 100 persons, and thereafter, at least one added lavatory for each additional 15 persons. $^{44}$ In July 1972, however, the Secretary published notice of a proposed informal

40. Id. at 36, reprinted in 3 U.S. CoDE CoNG. \& AD. News 5232 (1970).

41. See notes 26-33 supra and accompanying text.

42. 116 CONG. REC. 42,206 (1970). Although Congressman Steigler's remarks were directed toward permanent standards, his statements are equally applicable to national consensus and emergency temporary standards as all of the standards are subject to the same judicial review provision. See 29 U.S.C. $\$ 655(f)$ (1970). Indeed, the Court of Appeals for the Fifth Circuit has recently held that the substantial evidence test is to be applied to emergency standards. See Florida Peach Growers Ass'n, Inc. v. Department of Labor, 489 F.2d 120 (5th Cir. 1974).

43. 487 F.2d 342 (2d Cir. 1973).

44. 2 C.F.R. $\$ 1910.141$ (d)(2) (1971); 36 Fed. Reg. 10,593, 10,594 (1971). This standard was promulgated by the Secretary as a national consensus standard under section 655 (a) of OSHA. See note 8 supra. 
rulemaking proceeding to modify the standards previously adopted. ${ }^{45}$ Pursuant to this proceeding the Secretary promulgated revised standards which reduced the lavatory requirements for nonindustrial employment sites, yet left the requirements for industrial sites unchanged. ${ }^{46}$ Associated Industries challenged the Secretary's continued adherence to the former lavatories standard for industrial employment contending, inter alia, that such requirements were unsupported by substantial evidence. ${ }^{47}$ In response, the Secretary argued that the substantial evidence test required by the Act was only applicable to factual "determinations," that the development of standards from these facts was governed by informal rulemaking, and that the substantial evidence test was inapplicable to informal rulemaking. Therefore, the standards could be set aside only if arbitrary or capricious. ${ }^{48}$ In rejecting this argument, the Second Circuit held that standards issued under OSHA, as well as the findings on which they were based, are subject to the substantial evidence test, and that the standards in question were invalid under that test. ${ }^{49}$

The Second Circuit Court of Appeals thus confirmed what the Secretary of Labor lad earlier described as an anomaly-the application of the substantial evidence test to informal rulemaking procedures. $^{50}$ In so holding, the court rejected the Secretary's contention

45. 37 Fed. Reg. 13,996 (1972). In proposing this modification, the Secretary relied on the Act's general provisions, 29 U.S.C. $\$ 655(\mathrm{~b})(1970)$, governing the promulgation, modification, and recission of "permanent" standards under the Act. See note 13 supra for a description of the procedures outlined by section 655(b).

46. 38 Fed. Reg. 10,930, 10,933 (1973). Under the revised standards, nonindustrial sites were required to have only 5 lavatories for the first 125 einployees, with 1 added lavatory for each additional 45 employees. Id.

47. Brief for Petitioner at 4. Since the revised standards promulgated in May, 1973 retained the original requirements with respect to industrial sites and since the plaintiff in Associated Industries had failed to challenge the 1971 national consensus standard, see note 44 supra and accompanying text, within the 60-day time limitation applicable to challenges of standards under OSHA's judicial review provision, 29 U.S.C. $\S 665(f)$ (1970), the Secretary inaintained that the plaintiff was barred from attacking the 1973 standards. This argument was rejected by the court, however, which held that the prior standard, although identical in substance to the challenged 1973 standard for industrial establishments, was irrelevant to the validity of the 1973 standard and that Associated Industries was therefore free to make a timely challenge to the new proposed standards despite its failure to attack the earlier national consensus standard. 487 F.2d at 351.

48. Brief for Respondent at 12-17.

49. 487 F.2d at 349 .

50. The Secretary's position that the application of the substantial evidence standard to informal rulemaking is anomalous is not unique. Indeed, two commentators contend that Congress' attempt to apply the substantial evidence test to informal proceedings "mistakes the nature of the standard." Scalia \& Goodman 934. See text accompanying note 33 supra. 
that the paradoxical reference to a standard more vigorous than the substantial evidence test within the Conferee's report ${ }^{51}$ implicitly manifested a congressional intent to apply a narrower standard of review than that afforded by the substantial evidence test. ${ }^{52}$ In support of its interpretation, the court examined the legislative history of OSHA and concluded that the congressional intention to adopt the substantial evidence test in exchange for the deletion of the House's requirement for formal proceedings was apparent. ${ }^{53}$ Moreover, the court observed that the Department of Labor itself had previously recognized the apphicability of the substantial evidence standard in its regulations issued under OSHA. ${ }^{54}$ The Secretary further argued, however, that even if Congress' use of the substantial evidence standard in OSHA had been knowing and intentional, since OSHA specifically required only that the Secretary's "determinations" be supported by substantial evidence, the court should adopt a bifurcated standard of review to reconcile the apparent inconsistency in OSHA's application of the substantial evidence test to informal rulemaking. Under this approach, the Secretary's findings of fact would be subject to the substantial evidence test while the ultimate standard selected in light of those findings would be subject only to the arbitrary and capricious standard of review. ${ }^{55}$ In refuting this contention, the court noted that

51. See text accompanying note 40 supra.

52. 29 U.S.C. $\$ 655(f)(1970)$. See text accompanying note 16 supra. In arguing that the court was not inextricably bound by the wording of the statute in the face of an arguably inconsistent legislative history, the Secretary pointed to the language of the Supreine Court in its initial review of the APA:

It is fair to say that in all this Congress expressed a mood. And it expressed its mood not inerely by oratory but by legislation. As legislation that mood unust be respected, even though it can only serve as a standard for judgment and not as a body of rigid rules assuring sameness of application. Universal Camera Corp. v. NLRB, 340 U.S. 474, 487 (1951).

Thus, the Secretary argued that the language of the Conferee's report was sufficient to direct the courts to adopt a narrower standard of review than the substantial evidence test called for by the statutory language. Presumably that standard would be the arbitrary and capricious test.

53. $487 \mathrm{~F} .2 \mathrm{~d}$ at 349.

54. Id. With regard to the procedural and judicial review provisions of OSHA, the pertinent regulation, promulgated by the Department of Labor, provides the following statement:

Although these sections are not read as reqniring a rule making proceeding within the meaning of the last sentence of 5 U.S.C. [\$] 553(c) requiring the application of the formal requirements of 5 U.S.C. [\$\$] 556 and 557, they do snggest a Congressional expectation that the rule making would be on the basis of a record to which a substantial evidence test, where pertinent, may be applied in the event an informal hearing is held. 29 C.F.R. $\S$ $1911.15(a)(2)(1973)$.

55. In arguing for a bifurcated standard, the Secretary maintaimed that, even if the substantial evidence test were to be adopted, the Act required only that "the Secretary's 
the term "determinations" was used in such a manner throughout the Act as to "include the overall policy choices as well as factual findings [of the Secretary], and particularly to imclude [the] promulgation of standards." ${ }^{\text {" }}$ Applying the substantial evidence test, the court concluded that the Secretary had failed to produce any evidence justifying its action and invalidated the challenged standards. ${ }^{57}$

The effect of the court's decision in Associated Industries is to confirm the application of the substantial evidence test to the Secretary's determinations under the Act, including the health and safety standards promulgated thereunder. However, the court correctly observed that, given the informal rulemaking procedures provided in OSHA, the significance of their finding was essentially "semantic" rather than dispositive, ${ }^{58}$ stating:

While we still have a feeling that there may be cases where an adjudicative determination not supported by substantial evidence ... would not be regarded as arbitrary or capricious, ... in the review of rules of general applicability made after notice and comment rulemaking, the two criteria do tend to converge. ${ }^{59}$

Thus, the court apparently recognized that the significance of the substantial evidence test lay not in its imposition of a stricter standard of review per se, but rather in its application to a formal evidentiary record.

The provisions in OSHA which require that there be a hearmg upon objection to proposed rulemaking ${ }^{60}$ and that the Secretary's de-

'determinations' must be supported by substantial evidence, it does not provide that 'the Rule' should be so supported." Respondent's Brief at 14.

56. 487 F.2d at 348. Although the court based its conclnsion as to this point on the implicit meaning of the word "determinations" as used in the Act, id. at 348 n.5, explicit snpport for its decision may be found in Congressman Steigler's remarks. See note 42 supra and accompanying text. It is interesting to note that Congress made its intentions more explicit in the snbsequently enacted Consumer Product Safety Act, 15 U.S.C.A. §§ 2051-81 (Supp. 1974). Pursuant to that Act, a Commission's "findings," which are subject to the substantial evidence test, are statutorily described as inclnding the finding "that promulgation of the rule is in the pnblic interest." Id. $\S 2058(\mathrm{c})(2)(\mathrm{B})$.

57. 487 F.2d at $351-54$.

58. Id. at 349 .

59. Id. at 350. It should be noted that the Third Circuit has previously stated that the mere existence of the two standards as alternative grounds for judicial review indicated a legislative intention that the two tests should be construed as establishing different standards. Charlton v. Umited States, 412 F.2d 390, 398 (3d Cir. 1969) (Stahl, J., concurring). However, in Associated Industries, the Second Circuit indicated the difficulty in applying such a distinction by its statement that the "lack of [substantive] evidence to support the standards" made those standards "arbitrary and capricious." 487 F.2d at 352 .

60. 29 U.S.C. $\S 655(b)(3)$ (1970). See note 13 supra and accompanying text. 
termination be supported by substantial evidence ${ }^{61}$ suggest that Congress intended OSHA standards to be promulgated pursuant to formal on-the-record ruleinaking procedures. But Congress also manifested an intent not to impose upon the Secretary the burden of timeconsuming trial-type hearings. ${ }^{62}$ Clearly, to effectuate congressional intent fully, OSHA rulemaking procedures inust be structured so as to create a proper record for review yet at the same time to avoid the delay and expense inherent in rulemaking by formal adjudication. In recognition of this dual congressional purpose, the Secretary has issued regulations which provide for an informal hearing with a limited right of cross-examination on "crucial" issues. ${ }^{63}$ Moreover, the regulations require that "the hearing shall be reported verbatim and a transcript shall be available to any interested person." ${ }^{44}$ However, the regulations do not require that the Secretary present the substantive facts and information upon which he relies in proposing the standard either in his notice of proposed rulemaking or at the informal hearing. ${ }^{65}$ Consequently, such procedures allow the Secretary the freedom to base his decision on information which interested parties have neither had the opportunity to controvert nor examine. ${ }^{.6}$

61. Id. $\S 655(\mathrm{f})$.

62. Professor Hamilton has noted that former rulemaking procedures may be "time-consuming, expensive, and unduly burdensome on administrative agencies." Hamilton 1277, 1283-1313.

63. 29 C.F.R. $\$ 1911.15(b)(2)(1973)$.

64. $I d . \S(b)(3)$.

65. See id. § 1911.

66. The necessity for limiting the contents of the record to information which has been subjected to public comment is illustrated by the Consumer Product Safety Act of 1972, 15 U.S.C.A. §§ 2051 et seq. (Supp. 1974). That Act, like OSHA, provides for the application of the substantial evidence test to informal rulemaking procedures. 15 U.S.C.A. $\$ 2060$ (c) (Supp. 1974). Unlike OSHA, however, the Consumer Act defines the term "record" for the purpose of judicial review. As defined in that Act, the term "record" includes the "consumer product safety rule; any notice or proposal published pursuant to (the notice provisions of the Act); the transcript . . of any oral presentation; any written submission of interested parties; and any other information which the Commission considers relevant to such rule." 15 U.S.C.A. $\$ 2060$ (a) (Supp. 1974) (emphasis added). Although the purpose of the definition is obviously to limit the sources upon which the Consumer Products Safety Commission may rely to support its actions, it is apparent that the last clause of that definition leaves substantial room for the Commission to base its promulgation on material which was not made available to the public during the informal learings. Since the agency will therefore almost always be able to enter some arguably valid basis for its decision into the record without fear of controversion, it has becn suggested that the result of this clause is to restrict the judicial review to the arbitrary and capricious test. Scalia \& Goodman 936.

It should also be noted that one of the primary criticisms of informal rulemaking is the "apparent insensitivity of agencies to communications addressed to them." Ham- 
Since the substantial evidence test calls for consideration of all the evidence which can be gathered, both challenging as well as supporting the agency action under review, ${ }^{67}$ such procedures are insufficient to create a record to which the substantial evidence test may be ineaningfully applied. In order to effectively implement "a Congressional expectation that the rule making would be on the basis of a record to which a substantial evidence test . . . may be applied," it is suggested that the courts impose two additional requirements. First, prior to the initiation of the informal hearing, the Secretary should be required to introduce into the record any information upon which he intends to rely on the promulgation of a standard. ${ }^{60}$ This requirement would subject that information to public comment during the hearing. Second, after the hearing, if the Secretary decided to rely on information which he did not imitially introduce into the hearing, that information should then be made available for written comment and limited cross-examination. To avoid the necessity for reconvening the hearing, such cross-examination could be carried out through written interrogatories and written responses. ${ }^{70}$ Thus a reviewing court would have a record consisting of the Secretary's notice of proposed rulemaking, written comments subimitted to the Secretary, the transcript of any hearings, and any additional information made available by the Secretary subsequent to the hearing, with written comments and imterrogatories submitted with that information. ${ }^{71}$ Such procedures would appear consistent with the congres-

ilton 1314. By including these comments in the record which is reviewed by the court, agencies would either be required to tailor their decisions in light of the information or provide adequate support in the rccord to justify an alternative course of action.

67. See notes 32,33 supra and accompanying text.

68. 29 C.F.R. § 1911.15 (a)(2) (1973).

69. It should be noted that section 6(e) of OSHA, 29 U.S.C. $\$ 656(\mathrm{e})$ (1970), already requires that "[w]lienever the Secretary promulgates any standard . . . lie shall include a statement of the reasons for such action, which shall be published in the Federal Register." However, because the substantial evidence test entails a weighing of all the factors impinging upon the validity of an agency's action, this requirement would not necessarily elicit a sufficiently broad set of information to allow the effective application of the substantial evidence test.

70. In Mobil Oil Corp. v. FPC, 483 F.2d 1238, 1262-63 (D.C. Cir. 1973), the Court of Appeals for the District of Columbia Circuit noted that a primary consideration is that any procedure used to satisfy the substantial evidence test be a "mechanism whereby adverse parties can test, criticize and illuminate the flaws in the evidentiary basis being advanced ...." The court also noted that this procedure miglit be carried out through the use of "written questions and responses." Id. at 1263.

71. It should be noted that the suggested procedures could only apply where there is a hearing. Otherwise, the parties would be relegated to written comments. See 29 U.S.C. \& 655(b)(3) (1970). This latter procedure, when not preceded by a hearing, would not create a record based upon a sufficiently adverse examination of evidence 
sional intent expressed in OSHA and other recent federal regulatory statutes $^{72}$ to allow agencies to proinulgate rules in a more flexible manner than is prescribed by the formal requirements found in sections 7 and 8 of the APA, yet would at the same time ensure meaningful public participation in and effective judicial review of the rulemaking process. The utilization of such hybrid rulemaking procedures would significantly limit the unfettered exercise of agency discretion without imposing the delay and expense inherent in formal adjudicatory rulemaking.

to comply with the procedural requirements of the substantial evidence test. See notes 32, 33 supra. However, where there is insufficient controversy over the Secretary's proposed action to prompt interested parties to request a hearing, it would not seem inconsistent with the procedural requirements of OSHA to apply a narrower standard of review.

In this regard, it is worthwhile to contrast the procedural provisions of OSHA with those of the Natural Gas Act, 15 U.S.C. $\$ \$ 717$ et seq. (1970). As under the judicial review provisions of OSHA, agency actions taken pursuant to the Natural Gas Act are subject to the substantial evidence test. Id. $\S 717 \mathrm{r}(\mathrm{b})$. However, unlike OSHA, which makes a hearing optional at the request of an interested party, the Natural Gas Act requires a hearing as a part of the rulemaking procedures. Id. $\$ 717 \mathrm{~d}(\mathrm{a})$. Thus, in reviewing the Natural Gas Act, the Court of Appeals in the Mobil Oil case found that, although the Act did not require formal rulennaking procedures, the applicability of the substantial evidence test under that Act mandated that the required hearing be "some sort of adversary, adjudicative-type procedure" which provided for the examination and testing of the evidence by opposing parties. Mobil Oil Corp. v. FPC, 483 F.2d 1238, 1259-64 (D.C. Cir. 1973). Moreover, the court held that informal coinments, even if submitted by adverse parties, would not be sufficient to satisfy the procedural requirements of the substantial evidence test. Id. at 1260 .

Thus, where Congress makes applicable the substantial evidence test and also requires a hearing, interested parties are autonatically assured of receiving the full procedural protections accorded by the test. Where such a hearing is optional at the request of interested parties, however, such a request must be made to invoke the full requirements of the substantial evidence test.

72. See note 34 supra. 